\title{
Faktor-Faktor Yang Mempengaruhi Minat Nasabah Bergabung Di BMT Mutiara Sakinah Pekanbaru
}

\author{
Zulkifli \\ Fakultas Agama Islam Universitas Islam Riau (UIR) Pekanbaru \\ Jl. Kaharuddin Nasution No. 113 Perhentian Marpoyan Pekanbaru 28284 \\ Email : zulkifli_rusby@fis.uir.ac.id
}

\begin{abstract}
Abstrak: Penelitian ini dilatar belakangi oleh semakin berkembangnya Lembaga Keuangan Syariah (LKS) di Indonesia, salah satunya yakni dengan berdirinya Bait Al-Maal wa At-Tamwil (BMT). BMT merupakan suatu lembaga keuangan yang bersifat mikro atau kecil dengan menggunakan sistem bagi hasil yang sesuai dengan ketentuan-ketentuan Allah SWT. Kesadaran masyarakat mengenai lembaga dan transaksi yang sesuai syariah kini menjadi suatu pertimbangan penting bagi pihak lembaga untuk berpacu menarik minat nasabah bergabung di BMT Mutiara Sakinah Pekanbaru. Rumusan masalah dalam penelitian ini adalah faktor-faktor apa saja yang mempengaruhi minat nasabah bergabung di BMT Mutiara Sakinah Pekanbaru dan faktor mana yang paling dominan mempengaruhinya. Tujuan penelitian ini untuk mengetahui faktor-faktor apa saja yang mempengaruhi minat nasabah bergabung di BMT Mutiara Sakinah Pekanbaru dan faktor mana yang paling dominan mempengaruhi minat nasabah tersebut. Kerangka teori dalam penelitian ini adalah bahwa faktor yang mempengaruhi minat nasabah yaitu faktor kebudayaan, faktor sosial, faktor pribadi, faktor psikologis, dan faktor bauran pemasaran jasa. Jenis penelitian yang digunakan adalah desain kausalitas. Jenis data yang digunakan dalam penelitian ini adalah data primer dan data sekunder. Populasi dalam penelitian ini adalah seluruh nasabah yang bergabung di BMT Mutiara Sakinah Pekanbaru dari tahun 2012-2016 dengan sampel sebanyak 56 orang. Teknik pengambilan sampel dengan cara random sampling. Sedangkan teknik pengumpulan data adalah observasi dan kuesioner. Untuk menganalisis data digunakan analisis kualitatif dan kuantitatif. Dalam menganalisis data kuantitatif digunakan analisis regresi linier berganda di mana proses penghitungannya menggunakan SPSS for Windows Versi 23.0. Hasil penelitian menunjukkan bahwa kelima faktor yang mempengaruhi minat nasabah untuk bergabung di BMT Mutiara Sakinah Pekanbaru adalah faktor kebudayaan dengan nilai sebesar 1,047, faktor sosial dengan nilai sebesar -1,016, faktor pribadi dengan nilai sebesar 4,004 faktor psikologi sebesar 5,024, dan faktor bauran pemasaran jasa dengan nilai sebesar -0.485, dan dapat diketahui bahwa faktor yang paling dominan mempengaruhi minat nasabah bergabung di BMT Mutiara Sakinah Pekanbaru adalah faktor psikologis (X5) sebesar 5,024.
\end{abstract}

Kata Kunci : Minat, BMT, LKS, Ekonomi Syariah 


\section{PENDAHULUAN}

Lembaga keuangan syariah ada yang bersifat laba dan ada yang bersifat nirlaba atau tidak mengutamakan keuntungan, dimana lembaga keuangan syariah nirlaba yang saat ini berkembang antara lain: organisasi pengelola zakat, baik badan amil zakat maupun lembaga amil zakat dan badan wakaf bahkan lembaga keuangan syariah seperti BMT (Bait Al-Maal wa At-Tamwil) juga turut berkembang sangat pesat di Indonesia.

Seperti yang diketahui BMT merupakan Lembaga Keuangan Mikro Syariah (LKMS) yang dioperasikan dengan prinsip-prinsip bagi hasil atau sesuai dengan syariat Islam, dalam rangka menumbuhkembangkan usaha mikro dengan membantu atau memberikan dana kepada masyarakat menengah ke bawah untuk membuka usaha dan bagi yang membutuhkan. BMT merupakan salah satu lembaga keuangan non bank. Sebagai suatu Lembaga Keuangan, maka BMT juga memiliki fungsi-fungsi yang melekat ada pada suatu lembaga keuangan. Salah satu fungsi lembaga keuangan adalah menyediakan alat pembayaran yang sah, dalam hal ini uang yang diperoleh dari penghimpunan dana dan penyaluran dana tersebut kepada masyarakat yang memerlukan dana. Sesuai fungsi tersebut, maka lembaga keuangan dalam hal ini bisa dikatakan sebagai media yang mempertemukan antara pihak yang kelebihan dana dengan pihak yang memerlukan atau membutuhkan dana (Ridwan, 2004).

Salah satunya adalah BMT Mutiara Sakinah Pekanbaru, dimana BMT ini merupakan lembaga keuangan mikro syariah dimana berfungsi menghimpun dana dari masyarakat dan kemudian menyalurkannya kembali pada masyarakat yang membutuhkan dana serta memberikan jasa keuangan lainnya, sebagai usaha pengumpulan dan penyaluran dana komersial. BMT Mutiara Sakinah adalah koperasi simpan pinjam syariah untuk membangun dan mengembangkan ekonomi masyarakat dengan landasan syariah Islam. Sebagai Bait Al-Maal, kegiatan BMT dijalankan tidak mengutamakan adanya keuntungan (laba). BMT berfungsi sebagai mengemban amanah serta menyalurkan bantuan dana secara langsung kepada masyarakat atau pihak yang membutuhkan dana.

Bait Al-Maal wa At-Tamwil (BMT) Mutiara Sakinah berada di bawah Yayasan Lembaga Pendidikan Sakinah (YLPS) Riau, yang dipimpin oleh ketua Yayasan Lembaga Pendidikan Sakinah Bapak Dr. Zulkifli, MM. ME,Sy sejak tahun 2007. Hal ini didasari oleh kerisauan beliau terhadap ekonomi masyarakat sekitar Yayasan Lembaga Pendidikan Sakinah, dimana banyak sekali masyarakat yang menengah ke bawah yang tidak memiliki modal untuk membuka usaha dan kurang mampu untuk memenuhi kebutuhan hidupnya, sehingga beliau menghibahkan modal untuk mendirikan sebuah lembaga yang bernama BMT Mutiara Sakinah Pekanbaru.

Pada BMT Mutiara Sakinah Pekanbaru ini memiliki perbedaan dengan lembaga keuangan mikro yang lainnya, yaitu setiap orang yang ingin mengajukan pembiayaan tidak harus menjadi anggota selama tiga bulan terlebih dahulu, persyaratan pembiayaannya juga tidak dipungut anggunan atau jaminan karena yang meminjam ialah orang yang kebutuhannya menengah ke bawah sehingga pembayarannya berdasarkan kepercayaan kepada personal dari pihak lembaga kepada pihak nasabah.

Jadi, BMT Mutiara Sakinah Pekanbaru memberi kemudahan dan sangat membantu masyarakat menengah 
ke bawah yang membutuhkan, yang dibantu tidak hanya karyawan yang di dalam saja namun juga masyarakat di luar dan sekitar BMT Mutiara Sakinah Pekanbaru.

\section{TINJAUAN PUSTAKA}

\section{Teori Pelayanan}

Menurut Jahja, Yudrik (2015) minat adalah suatu dorongan yang menyebabkan terikatnya perhatian individu pada objek tertentu seperti pekerjaan pelajaran, benda dan orang. Minat berhubungan dengan aspek kognitif afektif dan motorik dan merupakan sumber motivasi untuk melakukan apa yang diinginkan.

Minat merupakan suatu keinginan yang timbul dari diri sendiri tanpa ada paksaan dari orang lain untuk mencapai suatu tujuan tertentu. Maka dari itu dapat disimpulkan bahwa minat menabung nasabah merupakan keinginan yang datang dari diri nasabah untuk menggunakan produk/jasa bank atau melakukan penyimpanan atas uang mereka di bank dengan tujuan tertentu (e-jurnal Rr.Indah Mustikawati: 2013).

\section{Faktor-Faktor Minat}

Untuk mengetahui faktor-faktor yang mempengaruhi minat nasabah dapat dilihat dari faktor-faktor berikut: (Alma, Buchari, 2011).

a. Social Factors, yaitu berupa grup-grup yang turut mempengaruhi, dimana seseorang masuk sebagai anggota, misalnya kelompok keluarga, teman, tetangga, teman sekerja, klub olahraga, klup seni, dan sebagainya.

b. Cultural Factors, yaitu faktor budaya yang begitu banyak kelompoknya, mulai dari kelompok Negara, sampai kelompok etnis/suku memiliki budaya dan kebiasaan dan adat sendiri. Di Negara kita ada budaya Sunda, Jawa, Minang, Batak, dan sebagainya. Masing-masing memiliki pola konsumsi dan barang kesenangan masing-masing.

c. Personal Factors, yang menyangkut masalah usia, pekerjaan, jabatan, keadaan ekonomi pribadi, gaya hidup, kepribadian.

d. Psychological Factors, yaitu menyangkut motivasi seseorang untuk membeli apakah mengikuti teori motivasi. Juga menyangkut masalah persepsi seseorang terhadap sesuatu.

\section{Sifat-Sifat dan Karakter Minat}

Menurut Jahja, Yudrik (2015) minat memiliki sifat-sifat dan karakter khusus, sebagai berikut :

a. Minat bersifat pribadi atau individual, dan ada perbedaan antara minat seseorang dengan orang lain.

b. Minat menimbulkan efek diskriminatif..

c. Erat hubungannya dengan motivasi.

\section{Perilaku Konsumen}

Menurut Sunyoto, Danang (2012) perilaku konsumen dapat didefinisikan sebagai kegiatan-kegiatan individu yang secara langsung terlibat dalam mendapatkan dan menggunakan barangbarang atau jasa, termasuk didalamnya proses pengambilan keputusan pada persiapan dan penentu kegiatan-kegiatan tersebut.

\section{Perilaku Konsumen Islami}

Perilaku konsumen Islami, terbentuk dari paradigma berpikir yang sama sekali berbeda dengan paradigma hukum permintaan yang kita kenal dalam ekonomi konvensional (Edwin, Mustafa, 2010).

Menurut Zulkifli (2015) untuk Sumber Daya Insani (SDI) lembaga keuangan syariah, juga dituntut untuk memahami ketentuan prinsip syariah yang baik serta memiliki akhlak dan moral Islami, yang dapat dijabarkan dan 
diselaraskan dengan sifat-sifat yang harus dipenuhi, yakni :

a. Siddiq, yakni bersikap jujur terhadap diri sendiri, terhadap orang dan Allah SWT.

b. Istiqomah, yakni bersikap teguh, sabar dan bijaksana.

c. Fathonah, yakni professional, disiplin, mentaati peraturan, bekerja keras dan inovatif.

d. Amanah, yakni penuh tanggungjawab dan saling menghormati dalam menjalankan tugas dan melayani mitra usaha.

e. Tabligh, yakni bersikap mendidik, membina, dan memotivasi pihak lain untuk meningkatkan fungsinya sebagai khalifah di muka bumi.

\section{Faktor-Faktor yang Mempengaruhi Minat Nasabah}

Keputusan pembelian dari pembeli sangat dipengaruhi oleh faktor-faktor kebudayaan, sosial, pribadi, psikologis, dan faktor bauran pemasaran.

1. Faktor Kebudayaan

Faktor-faktor kebudayaan terdiri dari (J.Setiadi, Nugroho, 2013):
a. Kebudayaan.
Kebudayaan merupakan faktor penentu yang paling dasar dari keinginan dan perilaku seseorang.

b. Subbudaya. Setiap kebudayaan terdiri dari subbudayasubbudaya yang lebih kecil yang memberikan identifikasi dan sosialisasi yang lebih spesifik untuk para anggotanya. Subbudaya dapat dibedakan menjadi empat jenis: kelompok nasionalisme, kelompok keagamaan, kelompok ras, dan area geografis.

c. Kelas sosial. Kelas-kelas sosial adalah kelompok yang relatif homogen dan bertahan lama dalam suatu masyarakat, yang tersusun secara hirarki dan keanggotaannya mempunyai nilai, minat, dan perilaku yang serupa.

2. Faktor Sosial

Faktor-faktor sosial terdiri dari (J.Setiadi, Nugroho, 2013) :

a. Kelompok . Kelompok seseorang terdiri-dari seluruh kelompok yang mempunyai pengaruh langsung maupun tidak langsung terhadap sikap atau perilaku seseorang.

b. Keluarga. Keluarga adalah kelompok sosial yang paling dominan dalam mempengaruhi perilaku konsumen. Kita dapat membedakan dua keluarga dalam kehidupan pembeli, yang pertama adalah: keluarga orientasi, yang merupakan orang tua seseorang.

c. Peran dan Status. Seseorang umumnya berpartisipasi dalam kelompok selama hidupnya keluarga, klub, organisasi. Posisi seseorang dalam setiap kelompok dapat diidentifikasikan dalam peran dan status.

3. Faktor Pribadi

Faktor-faktor pribadi terdiri dari (J.Setiadi, Nugroho, 2013):

a. Usia dan tahapan dalam siklus hidup. Konsumsi seseorang juga dibentuk oleh tahapan siklus hidup keluarga. Beberapa penelitian terakhir telah mengidentifikasi tahapantahapan dalam siklus hidup psikologis

b. Pekerjaan. Para pemasar berusaha mengidentifikasi kelompok-kelompok pekerja yang memiliki minat di atas rata-rata terhadap produk atau jasa-jasa tertentu. 
c. Keadaan ekonomi. Yang dimaksud dengan keadaan ekonomi seseorang adalah terdiri dari pendapatan yang dapat dibenlanjakan (tingkatnya, stabilitasnya, dan polanya), tabungan dan hartanya (termasuk persentase yang mudah dijadikan uang), kemampuan untuk meminjam dan sikap terhadap mengeluarkan lawan menabung.

d. Gaya hidup. Gaya hidup seseorang adalah pola hidup di dunia yang diekspresikan oleh kegiatan, minat dan pendapat seseorang. Gaya hidup menggambarkan "seseorang secara keseluruhan" yang berinteraksi dengan lingkungan. Gaya hidup juga mencerminkan sesuatu di balik kelas sosial seseorang.

e. Kepribadian. Yang dimaksud dengan kepribadian adalah karakteristik psikologis yang berbeda dan setiap orang memandang responnya terhadap lingkungan yang relatif konsisten.

4. Faktor Psikologis

Faktor-faktor psikologis terdiri dari (J.Setiadi, Nugroho, 2013) :

a. Motivasi. Beberapa kebutuhan bersifat biogenik, kebutuhan ini timbul dari suatu keadaan fisiologis tertentu seperti rasa lapar, haus, resah tidak nyaman. Adapun kebutuhan lain bersifat psikogenik, yaitu kebutuhan yang timbul dari keadaan fisiologis tertentu, seperti kebutuhan untuk diakui, kebutuhan harga diri atau kebutuhan diterima.

b. Persepsi. Persepsi didefinisikan sebagai proses dimana seseorang memilih, mengorganisasikan, mengartikan masukan informasi, untuk menciptakan suatu gambaran yang berarti dari dunia ini.

c. Proses belajar. Proses belajar menjelaskan perubahan dalam perilaku seseorang yang timbul dari pengalaman.

d. Kepercayaan dan sikap. Kepercayaan adalah suatu gagasan deskriptif yang dimilliki seseorang terhadap sesuatu.

5. Faktor Bauran Pemasaran Jasa

Menurut Sunyoto, Danang (2012) Bauran pemasaran (marketing mix) adalah seperangkat alat taktik pemasaran yang terkendali dan diramu untuk mendapat tanggapan dari pasar sasaran.

Sebagai suatu bauran unsurunsur tersebut saling mempengaruhi strategi pemasaran secara keseluruhan, dengan demikian, unsur bauran pemasaran jasa terdiri-dari tujuh hal sebagai berikut (Hermawan, Agus, 2013).

Menurut Sunyoto, Danang (2012) Bauran pemasaran jasa terdiri atas sebagai berikut :

a. Product (Produk) Merupakan keseluruhan konsep objek atau proses yang memberikan sejumlah nilai manfaat kepada konsumen.

b. Price (Harga). Keputusan bauran harga berkenaan dengan kebijakan strategis dan taktis, seperti tingkat harga, struktur diskon, cara pembayaran dan tingkat diskriminasi harga diantara berbagai kelompok pelanggan.

c. Promotion (Promosi) adalah pemilihan bauran promosi yang terdiri-dari: periklanan, penjualan perorangan, promosi penjualan dan hubungan masyarakat. 
d. Place (Tempat) merupakan keputusan atas dasar saluran distribusi, dalam hal ini berhubungan dengan bagaimana cara penyampaian jasa kepada nasabah dan dimana lokasi yang strategis.

e. People (Orang). Dalam hubungannya dengan pemasaran jasa, maka people yang berfungsi sebagai service provider (penyedia layanan) sangat mempengaruhi kualitas jasa yang diberikan.

f. Process (Proses) merupakan gabungan semua aktivitas, umumnya terdiri dari prosedur, jadwal pekerjaan, mekanisme, aktivitas dan hal-hal rutin, dimana jasa dihasilkan dan disampaikan kepada konsumen.

g. Customer service (Layanan Konsumen). Pada pemasaran jasa lebih dilihat sebagai hasil dari kegiatan distribusi dan logistik, dimana pelayanan diberikan kepada konsumen untuk mencapai kepuasan. Layanan konsumen meliputi aktivitas untuk memberikan kegunaan waktu dan tempat termasuk pelayanan bertransaksi akan turut mempengaruhi kegiatan transaksi dan setelah transaksi, karena itu kegiatan pendahuluannya harus sebaik mungkin sehingga konsumen memberikan respon yang positif yang menunjukkan loyalitas yang tinggi.

\section{Bait Al-Maal wa At-Tamwil}

\section{Pengertian Bait Al-Maal wa At-Tamwil}

Sedangkan menurut Soemitra, Andri (2010) BMT adalah kependekan dari kata Balai Usaha Mandiri Terpadu atau Baitul Maal wat Tamwil, yaitu Lembaga Keuangan
Mikro (LKM) yang beroperasi berdasarkan prinsip-prinsip syariah.

BMT sesuai namanya terdiri dari dua fungsi utama, yaitu sebagai berikut:

a. Bait At-Tamwil (rumah pengembangan harta), melakukan kegiatan pengembangan usaha-usaha produktif dan investasi dalam menigkatkan kualitas ekonomi pengusaha mikro dan kecil dengan antara lain mendorong kegiatan menabung dan menunjang pembiayaan kegiatan ekonomi.

b. Bait Al-Maal (rumah harta), menerima titipan dan zakat, infak dan sedekah serta mengoptimalkan distribusinya sesuai dengan peraturan dan amanahnya.

\section{Tujuan BMT}

Menurut Rodoni, Ahmad (2008) sebagai salah satu lembaga perekonomian umat, BMT memiliki beberapa tujuan, antara lain:

a. Meningkatkan dan mengembangkan potensi umat dalam program pengentasan kemiskinan, khususnya pengusaha kecil atau lemah.

b. Menciptakan sumber pembiayaan dan penyediaan modal bagi anggota dengan prinsip syariah.

c. Membantu para pengusaha lemah untuk mendapatkan modal pinjaman dan membebaskan dari sistem riba.

\section{Fungsi BMT}

Menurut Zulkifli (2015) fungsi BMT secara umum adalah sebagai berikut:

a. Penghimpunan dana dan penyaluran dana, dengan menyimpan uang di BMT, uang tersebut dapat ditingkatkan utilitanya, sehingga timbul unit surplus (pihak yang memiliki dana berlebih) dan unit defisit (pihak yang kekurangan dana).

b. Pencipta dan pemberi likuiditas, dapat menciptakan alat pembayaran yang sah yang mampu memberikan kemampuan 
untuk memenuhi kewajiban suatu lembaga/perorangan.

c. Sumber pendapatan, BMT dapat menciptakan lapangan kerja dan memberi pendapatan kepada para pegawainya.

d. Pemberi informasi, memberi informasi kepada masyarakat mengenai resiko keuntungan dan peluang yang ada pada lembaga tersebut.

Selain itu BMT juga memiliki beberapa peranan, di antaranya adalah sebagai berikut:

a. Menjauhkan masyarakat dari praktek ekonomi yang bersifat non Islam. Aktif melakukan sosialisasi di tengah masyarakat tentang arti penting sistem ekonomi Islami.

b. Melakukan pembinaan dan pendanaan usaha kecil. BMT harus bersifat aktif menjalankan fungsi sebagai lembaga keuangan mikro, misalnya dengan jalan pendampingan, pembinaan, penyuluhan, dan pengawasan usaha-usaha nasabah.

c. Melepaskan ketergantungan masyarakat yang masih tergantung pada rentenir disebabkan mampu memenuhi keinginan masyarakat dalam memenuhi dana dengan segera. (Huda, Nurul dan Mohammad Heykal, 2010).

Selain itu juga peran BMT di masyarakat terdapat beberapa aspek, yaitu sebagai berikut:

a. Motor penggerak ekonomi dan sosial masyarakat banyak.

b. Ujung tombak pelaksanaan sitem ekonomi Islam.

c. Menghubungkan antara kaum Aqhniya' (kaya) dan kaum Dhuafa (miskin).

d. Sarana pendidikan informal untuk menunjukkan prinsip hidup yang barokah.

\section{Keunggulan BMT}

Menurut Rodoni, Ahmad (2008) BMT memiliki beberapa keunggulan, yaitu : a. Prinsip bagi hasil.

b. Adanya jaminan pelayanan jasa keuangan berdasarkan prinsip syariah dan bebas dari praktek riba.

c. Adanya pemerataan dan keseimbangan dalam perolehan keuntungan.

d. Masing-masing pihak antara BMT dan nasabah dapat berbagi resiko karena masing-masing memiliki hak dan kewajiban yang sama sesuai dengan proporsinya.

\section{Ciri-Ciri Utama BMT}

Menurut Soemitra, Andri (2010) ciriciri utama dari BMT itu sendiri adalah :

a. Berorientasi bisnis, mencari laba bersama meningkatkan pemanfaatan ekonomi paling banyak untuk anggota dan lingkungannya.

b. Bukan lembaga sosial tetapi dapat dimanfaatkan untuk mengefektifkan penggunaan zakat infaq dan sedekah bagi kesejahteraan orang banyak.

c. Ditumbuhkan dari bawah berlandaskan peran serta masyarakat disekitarnya.

d. Milik bersama masyarakat kecil dan bawah dari lingkungan BMT itu sendiri, bukan milik orang seorang atau orang dari luar masyarakat itu.

Di samping ciri-ciri utama tersebut, BMT juga memiliki ciri-ciri khusus, yaitu:

a. Staf dan karyawan BMT bertindak aktif, dinamis, berpandangan, produktif, tidak menunggu tetapi menjemput nasabah, baik sebagai penyetor dana maupun sebagai penerima pembiayaan usaha.

b. Kantor dibuka dalam waktu tertentu dan ditunggu oleh jumlah staf yang terbatas, karena sebagian besar staf harus bergerak di lapangan untuk mendapatkan nasabah penyetor dana, monitor, dan mensuprivisi usaha nasabah.

c. BMT mengadakan pengajian rutin secara berkala yang waktu dan tempatnya, biasanya di Madrasah, Masjid atau 
Mushalla, ditentukan sesuai dengan kegiatan nasabah dan anggota BMT. Setelah pengajian biasanya dilanjutkan dengan pembicaraan bisnis dari pada nasabah BMT.

d. Membantu dan memberikan kemudahan pada masyarakat menengah ke bawah yang sedang membutuhkan (Zulfa, 2019).

\section{Landasan Hukum Bait Al-Maal wa At- Tamwil}

a. Sumber landasan hukum Bait Al-Maal wa At-Tamwil

1. Al-Qur'an dalam surat Al-Baqarah ayat: 261 adalah sebagai berikut :
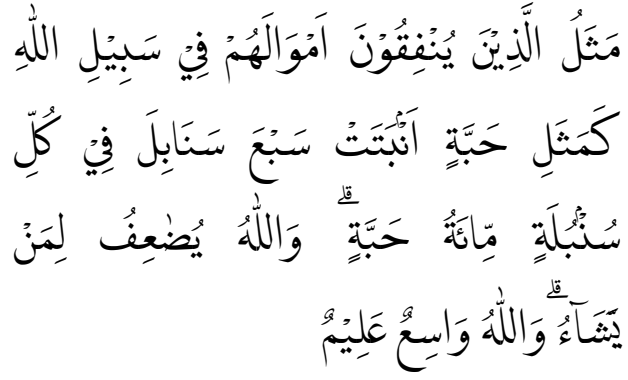

Artinya: "Perumpamaan orang-orang yang menafkahkan hartanya mereka dijalan Allah adalah serupa dengan butir benih yang menumbuhkan tujuh butir, pada setiap butir seratus biji. Allah (terusmenerus) melipat gandakan bagi siapa yang Dia kehendaki. Dan Allah maha luas (karuniaNya) Lagi Maha Mengetahui”. (Departeman Agama, RI, 2009).

2. Al-Hadits

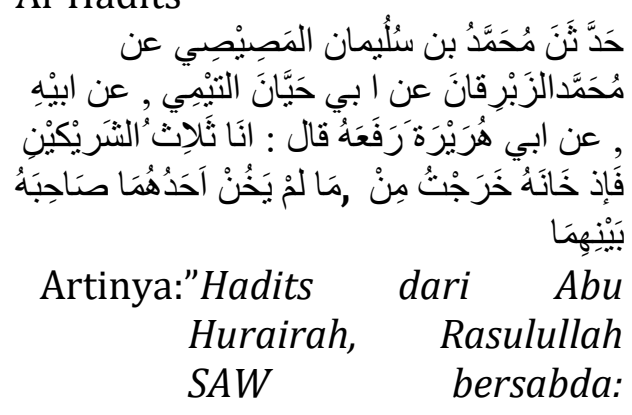

Sesungguhnya Allah azza wajalla berfirman "Äku pihak ketiga dari dua orang yang berserikat selama salah satunya tidak menghianati lainnya." (Abu Dawud hlm. 609, no. 3383 Lihat juga Nailul Authar 5/264).

\section{Fatwa DSN}

Fatwa DSN-MUI No.02/ DSNMUI/IV/2000 tentang dana yang disimpan nasabah akan dikelola BMT untuk memperoleh keuntungan. Keuntungan akan diberikan kepada nasabah berdasarkan kesepakatan nasabah. Nasabah bertindak sebagai shahibul maal dan BMT bertindak sebagai mudharib (Nurul Huda, 2012).

b. Regulasi BMT

BMT berazaskan Pancasila dan UUD 1945 serta berlandaskan syariah Islam, secara hukum BMT berpayung pada koperasi tapi sistem operasionalnya tidak jauh berbeda dengan bank syariah karena berbadan hukum koperasi BMT harus tunduk pada UU Nomor 25 tahun 1992 tentang perkoperasian dan PP (Peraturan Pemerintah) Nomor 9 tahun 1995 tentang pelaksanaan usaha simpan pinjam oleh koperasi. Juga dipertegas dengan KEP.MEN Nomor 91 tahun 2004 tentang koperasi jasa keuangan syariah. Undang-undang tersebut sebagai payung berdirinya BMT.

\section{METODE}

Penelitian ini termasuk penelitian kausalitas yaitu penelitian yang disusun untuk meneliti kemungkinan adanya hubungan sebab-akibat antarvariabel (Sanusi, Anwar, 2016). Penelitian ini bertujuan untuk mengetahui faktor-faktor yang mempengaruhi minat nasabah bergabung di BMT Mutiara Sakinah 
Pekanbaru. Penelitian ini dilakukan di BMT Mutiara Sakinah Pekanbaru yang berada di JL. Gading Marpoyan Blok A No.12 Pekanbaru Riau. Penelitian ini dilakukan pada bulan September 2017 sampai bulan Desember 2017, yaitu selama empat bulan.

Dalam penelitian ini yang dijadikan populasi adalah seluruh nasabah yang bergabung di BMT Mutiara Sakinah Pekanbaru dari tahun 2012-2016 sebanyak 127 orang. Dari jumlah populasi, maka penulis melakukan pengambilan sampel. Adapun jumlah sampel ditentukan berdasarkan rumus Slovin berjumlah 55.95 Nasabah. Sebagai subjek penelitian ini adalah nasabah yang bergabung di Mutiara Sakinah Pekanbaru dan Objeknya adalah faktor-faktor yang mempengaruhi minat nasabah bergabung di BMT Mutiara Sakinah Pekanbaru. Sumber data berupa data primer dan data sekunder, teknik pengumpulan data menggunakan angket dan dokumentasi. Teknik pengolahan data penyuntingan (editing), pengkodean (coding) dan pentabulasian (tabulating).
Analisis data yang digunakan dalam penelitian ini adalah analisis kualitatif dan kuantitatif. Analisis kualitatif yaitu analisis yang digunakan untuk penganalisaan secara argumentatif berdasarkan data-data yang bersifat karakteristik (jenis kelamin, umur) atas jawaban kuesioner yang diperoleh dari nasabah yang bergabung di BMT Mutiara Sakinah Pekanbaru. Sedangkan analisis kuantitatif digunakan untuk menganalisis secara statistik guna melakukan uji penelitian terhadap datadata yang diperoleh dengan menggunakan analisis regresi linear berganda dimana proses penghitungannya menggunakan SPSS for Windows versi 23.0.

\section{HASIL DAN PEMBAHASAN Uji Validitas}

Pengukuran validitas dilakukan dengan menggunakan rumus Corrected Item-Total Correlation dengan taraf signifikan $5 \quad(\alpha=0,05)$ artinya suatu item dianggap valid jika berkorelasi signifikan terhadap skor total.

Tabel 1: Hasil Uji Validitas

\begin{tabular}{|c|c|c|c|c|}
\hline Variabel & $\begin{array}{c}\text { Item } \\
\text { Pernyataan }\end{array}$ & $\begin{array}{c}\text { Corrected } \\
\text { Item-Total } \\
\text { Correlation } \\
\text { (r Hitung) }\end{array}$ & $\begin{array}{c}\mathbf{r} \text { tabel } \\
\mathbf{\alpha = 0 , 0 5}\end{array}$ & Keterangan Hasil \\
\hline \hline $\mathbf{X}$ & Item 1 & 0.509 & 0.263 & Valid \\
\hline & Item 2 & 0.649 & 0.263 & Valid \\
\hline & Item 3 & 0.594 & 0.263 & Valid \\
\hline & Item 4 & 0.765 & 0.263 & Valid \\
\hline & Item 5 & 0.859 & 0.263 & Valid \\
\hline & Item 6 & 0.756 & 0.263 & Valid \\
\hline & Item 7 & 0.505 & 0.263 & Valid \\
\hline & Item 8 & 0.578 & 0.263 & Valid \\
\hline & Item 9 & 0.725 & 0.263 & Valid \\
\hline & Item 10 & 0.778 & 0.263 & Valid \\
\hline & Item 11 & 0.639 & 0.263 & Valid \\
\hline & Item 12 & 0.820 & 0.263 & Valid \\
\hline & Item 13 & 0.778 & 0.263 & Valid \\
\hline & Item 14 & 0.704 & 0.263 & Valid \\
\hline & Item 15 & 0.696 & 0.263 & Valid \\
\hline
\end{tabular}




\begin{tabular}{|c|c|c|c|c|}
\hline & Item 16 & 0.786 & 0.263 & Valid \\
\hline & Item 17 & 0.862 & 0.263 & Valid \\
\hline & Item 18 & 0.682 & 0.263 & Valid \\
\hline & Item 19 & 0.837 & 0.263 & Valid \\
\hline & Item 20 & 0.834 & 0.263 & Valid \\
\hline & Item 21 & 0.868 & 0.263 & Valid \\
\hline & Item 22 & 0.867 & 0.263 & Valid \\
\hline \hline Y & Item 23 & 0.768 & 0.263 & Valid \\
\hline & Item 24 & 0.807 & 0.263 & Valid \\
\hline & Item 25 & 0.829 & 0.263 & Valid \\
\hline & Item 26 & 0.847 & 0.263 & Valid \\
\hline & Item 27 & 0.703 & 0.263 & Valid \\
\hline & Item 28 & 0.667 & 0.263 & Valid \\
\hline
\end{tabular}

Sumber: Data Olahan SPSS Versi 23.0

Diketahui nilai $r$ tabel sebesar 0,263 (lihat tabel $r$ ) dan nilai ini dibandingkan dengan nilai $r$ hitung. Nilai $r$ hitung dalam uji ini adalah pada kolom Item-Total Statistics (Corrected Item-Total Correlation). Dan dari tabel diatas menunjukkan bahwa butir pernyataan mempunyai nilai korelasi yang lebih besar dari $r$ tabel. Sehingga seluruh item-item variabel dinyatakan valid dan layak untuk dianalisis.

\section{Uji Reliabilitas}

Uji reliabilitas digunakan teknik Cronbach Alpha dimana instrumen dapat dikatakan handal atau reliabel bila memiliki koefisien kehandalan sebesar $>0,6$. Reliabilitas ini akan dilakukan pada butir-butir pernyataan yang telah memiliki kevalidan pada uji validitas sebelumnya. Dan jumlah butir pernyataan yang dapat diuji pada uji reliabilitas ini sebanyak 28 butir.

Tabel 2: Hasil Uji Reliabilitas

\begin{tabular}{|c|c|c|}
\hline Variabel & Koefisien Alpha & Keterangan Hasil \\
\hline X1 & 0.517 & Reliabel \\
X2 & 0.602 & Reliabel \\
X3 & 0.362 & Reliabel \\
X4 & 0.369 & Reliabel \\
X5 & 0.678 & Reliabel \\
Y & 0.305 & Reliabel \\
\hline
\end{tabular}

Sumber: Data Olahan SPSS Versi 23.0

Berdasarkan uji validitas dengan menggunakan korelasi product moment dan uji reliabelitas menggunakan cronbach's alpha di atas dapat disimpulkan bahwa 28 butir pernyataan tentang faktor-faktor yang mempengaruhi minat nasabah bergabung di BMT Mutiara Sakinah Pekanbaru dinyatakan valid dan reliabel untuk mengukur variabel.

\section{Uji Hipotesis}

Uji hipotesis yang digunakan dalam penelitian ini ada 5 (lima) yaitu:

\section{a) Analisis Regresi Berganda}

Hasil perhitungan analisis regresi linier berganda melalui SPSS for Windows versi 23.0, maka diperoleh nilai-nilai untuk variabel bebas dan variabel terikat dapat dilihat pada tabel berikut: 
Tabel 3: Analisis Regresi Berganda Coefficients $^{a}$

\begin{tabular}{|c|c|c|c|c|c|}
\hline \multirow[b]{2}{*}{ Model } & \multicolumn{2}{|c|}{ Unstandardized Coefficients } & \multirow{2}{*}{$\begin{array}{c}\begin{array}{c}\text { Standardized } \\
\text { Coefficients }\end{array} \\
\text { Beta }\end{array}$} & \multirow[b]{2}{*}{$\mathrm{T}$} & \multirow[b]{2}{*}{ Sig. } \\
\hline & B & Std. Error & & & \\
\hline 1 (Constant) & -.605 & 4.024 & & -.150 & .881 \\
\hline faktor kebudayaan & .207 & .197 & .088 & 1.047 & .300 \\
\hline faktor sosial & -.128 & .126 & -.085 & -1.016 & .315 \\
\hline faktor pribadi & .596 & .149 & .405 & 4.004 & .000 \\
\hline faktor psikologis & .827 & .165 & .510 & 5.024 & .000 \\
\hline $\begin{array}{l}\text { faktor bauran } \\
\text { pemasaran jasa }\end{array}$ & -.037 & .076 & -.041 & -.485 & .630 \\
\hline
\end{tabular}

a. Dependent Variable: minat nasabah

Sumber: Data Olahan SPSS Versi 23.0

Berdasarkan tabel di atas, maka dapat disusun persamaan regresi berganda sebagai berikut:

$\mathrm{Y}=\mathrm{a}+b_{1} \mathrm{X}_{1}+b_{2} \mathrm{X}_{2}+b_{3} \mathrm{X}_{3}+b_{4} \mathrm{X}_{4}+b_{5} \mathrm{X}_{5}$

$\mathrm{Y}=-0,605+0,088 \mathrm{X}_{1}+-0.085 \mathrm{X}_{2}+$

$0,405 X_{3}+0,510 X_{4}+-0,041 X_{5}$

Arti angka-angka dalam persamaan regresi di atas adalah:

1) Nilai konstanta (a) sebesar -0,605 Artinya adalah apabila Kebudayaan, Sosial, Pribadi, Psikologis, Bauran Pemasaran jasa diasumsikan nol (0), maka Minat Nasabah (Y) bernilai 0,605 .

2) Nilai koefisien regresi variabel Kebudayaan $\left(\mathrm{X}_{1}\right)$ sebesar 0,088 . Artinya adalah bahwa setiap peningkatan Faktor Kebudayaan sebesar 1 satuan maka akan meningkatkan Minat nasabah (Y) sebesar 0,088 dengan asumsi variabel $\mathrm{X}_{2}, \mathrm{X}_{3}, \mathrm{X}_{4}$, dan $\mathrm{X}_{5}$ tetap.

3) Nilai koefisien regresi variabel Sosial $\left(\mathrm{X}_{2}\right)$ sebesar -0,085. Artinya adalah bahwa setiap penurunan Faktor Kebudayaan sebesar 1 satuan maka akan menurunkan Minat Nasabah (Y) sebesar -0,085 dengan asumsi variabel $\mathrm{X}_{1}, \mathrm{X}_{3}, \mathrm{X}_{4}$, dan $\mathrm{X}_{5}$ tetap.

4) Nilai koefisien regresi variabel Pribadi $\left(\mathrm{X}_{3}\right)$ sebesar 0,405. Artinya adalah

bahwa setiap peningkatan Faktor Kebudayaan sebesar 1 satuan maka akan meningkatkan Minat Nasabah (Y) sebesar 0,405 dengan asumsi variabel $\mathrm{X}_{1}, \mathrm{X}_{2}, \mathrm{X}_{4}$, dan $\mathrm{X}_{5}$ tetap.

5) Nilai koefisien regresi variabel Psikologis $\left(\mathrm{X}_{4}\right)$ sebesar 0,510 . Artinya adalah bahwa setiap peningkatan Faktor Kebudayaan sebesar 1 satuan maka akan meningkatkan Minat Nasabah (Y) sebesar 0,510 dengan asumsi variabel lain tetap.

6) Nilai koefisien regresi variabel Bauran Pemasaran Jasa $\left(\mathrm{X}_{5}\right)$ sebesar -0,041. Artinya adalah bahwa setiap penurunan Faktor Kebudayaan sebesar 1 satuan maka akan menurunkan Minat Nasabah (Y) sebesar $-0,041$ dengan asumsi variabel $\mathrm{X}_{1}, \mathrm{X}_{2}, \mathrm{X}_{3}, \mathrm{X}_{4}$ tetap.

\section{b) Uji Parsial (Uji-t)}

Uji-t dilakukan untuk mengetahui faktor yang mana yang paling dominan antara variabel bebas dan variabel terikat dengan menggunakan Uji Parsial (Uji-t) dengan menggunakan bantuan komputer program SPSS for Windows versi 23.0 maka dapat dilihat tabel dibawah ini: 
Tabel 4: Perhitungan Uji-t

Coefficients $^{\mathrm{a}}$

\begin{tabular}{|c|c|c|c|c|c|}
\hline \multirow[b]{2}{*}{ Model } & \multicolumn{2}{|c|}{ Unstandardized Coefficients } & \multirow{2}{*}{$\begin{array}{c}\begin{array}{c}\text { Standardized } \\
\text { Coefficients }\end{array} \\
\text { Beta }\end{array}$} & \multirow[b]{2}{*}{$\mathrm{T}$} & \multirow[b]{2}{*}{ Sig. } \\
\hline & B & Std. Error & & & \\
\hline 1 (Constant) & -.605 & 4.024 & & -.150 & .881 \\
\hline faktor kebudayaan & .207 & .197 & 088 & 1.047 & .300 \\
\hline faktor sosial & -.128 & .126 & -.085 & -1.016 & .315 \\
\hline faktor pribadi & .596 & .149 & .405 & 4.004 & .000 \\
\hline faktor psikologis & .827 & .165 & .510 & 5.024 & .000 \\
\hline $\begin{array}{l}\text { faktor bauran } \\
\text { pemasaran jasa }\end{array}$ & -.037 & .076 & -.041 & -.485 & .630 \\
\hline
\end{tabular}

a. Dependent Variable: minat nasabah

Sumber: Data Olahan SPSS Versi 23.0

Dari hasil pengolahan pada tabel 23 dapat diketahui bahwa:

1. Nilai thitung variabel kebudayaan (X1) sebesar 1,047 dan nilai tabel sebesar 2,009 dengan tingkat signifikan sebesar 0,05 dan derajat kebebasan sebesar 50 (dk=n-k-1(56-5-1)) maka akan terlihat

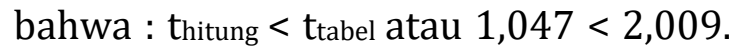
Hal ini menunjukkan bahwa Ho diterima dan Ha ditolak, sehingga dapat dikatakan bahwa tidak terdapat pengaruh yang signifikan antara kebudayaan terhadap minat nasabah.

2. Nilai thitung variabel sosial (X2) sebesar 1.016 dan nilai ttabel sebesar 2,009 dengan tingkat signifikan sebesar 0,05 dan derajat kebebasan sebesar 50 (dk=n-k-1(56-5-1)) maka akan terlihat

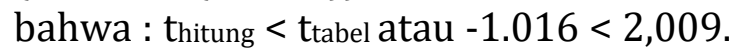
Hal ini menunjukkan bahwa Ho diterima dan Ha ditolak, sehingga dapat dikatakan bahwa tidak terdapat pengaruh yang signifikan antara sosial terhadap minat nasabah.

3. Nilai thitung variabel Pribadi (X3) sebesar 4.004 dan nilai ttabel sebesar 2,009 dengan tingkat signifikan sebesar 0,05 dan derajat kebebasan sebesar 50 ( $\mathrm{dk}=\mathrm{n}-\mathrm{k}-1(56-5-1)$ ) maka akan terlihat bahwa : thitung $>$ ttabel atau 4,004 > 2,009. Hal ini menunjukkan bahwa Ho ditolak dan Ha diterima, sehingga dapat

dikatakan bahwa terdapat pengaruh yang signifikan antara pribadi terhadap minat nasabah.

4. Nilai thitung variabel Psikologis (X4) sebesar 5.024 dan nilai tabel sebesar 2,009 dengan tingkat signifikan sebesar 0,05 dan derajat kebebasan sebesar 50 (dk=n-k-1(56-5-1)) maka akan terlihat bahwa : thitung $>$ ttabel atau 5,024 > 2,009. Hal ini menunjukkan bahwa Ho ditolak dan Ha diterima, sehingga dapat dikatakan bahwa terdapat pengaruh yang signifikan antara psikologis terhadap minat nasabah.

5. Nilai thitung variabel Bauran Pemasaran Jasa (X5) sebesar -0,485 dan nilai tabel sebesar 2,009 dengan tingkat signifikan sebesar 0,05 dan derajat kebebasan sebesar 50 (dk=n-k-1(56-5-1)) maka akan terlihat bahwa : thitung $<t_{\text {tabel }}$ atau $0,485<2,009$. Hal ini menunjukkan bahwa Ho diterima dan Ha ditolak, sehingga dapat dikatakan bahwa tidak terdapat pengaruh yang signifikan antara bauran pemasaran jasa terhadap minat nasabah.

Maka secara parsial dapat diketahui bahwa variabel bebas yang mempunyai pengaruh paling dominan mempengaruhi minat nasabah untuk bergabung di BMT Mutiara Sakinah Pekanbaru adalah faktor psikologis $\left(\mathrm{X}_{4}\right)$ dengan nilai sebesar 5.024. 


\section{c) Uji Simultan (Uji-F)}

Uji-F digunakan untuk mengetahui pengaruh masing-masing variabel bebas terhadap variabel terikat. Hasil pengujian uji-F tersebut adalah sebagai berikut:

Tabel 5 : Perhitungan Uji-F

\begin{tabular}{|c|l|r|r|r|r|l|}
\hline \multicolumn{2}{|c|}{ Model } & $\begin{array}{c}\text { Sum of } \\
\text { Square }\end{array}$ & \multicolumn{1}{c|}{ Df } & $\begin{array}{c}\text { Mean } \\
\text { Square }\end{array}$ & F & \multicolumn{1}{c|}{ Sig. } \\
\hline \multirow{2}{*}{1} & Regression & 368.339 & 5 & 73.668 & 21.091 & $.000^{\mathrm{b}}$ \\
\cline { 2 - 7 } & Residual & 174.644 & 50 & 3.493 & & \\
\cline { 2 - 7 } & Total & 542.982 & 55 & & & \\
\hline
\end{tabular}

Sumber : Data Olahan SPSS Versi 23.0

Dari tabel 24, menunjukkan bahwa Fhitung sebesar 21,091 sedangkan Ftabel pada taraf signifikan $(\alpha) 5$ dengan df 1 sebesar 5 (k-1=6-1), df 2 sebesar 50 (n$\mathrm{k}-1=56-5-1)$, maka Ftabel diperoleh sebesar 2,40.

Maka $F_{\text {hitung }}>\mathrm{F}_{\text {tabel }}$ yaitu 21,091 > 2,40 yang berarti bahwa Ho ditolak. Artinya adalah ada pengaruh yang sangat signifikan dari faktor kebudayaan, sosial, pribadi, psikologis dan bauran pemasaran jasa terhadap minat nasabah bergabung di BMT Mutiara Sakinah
Pekanbaru, dimana nilainya sebesar 21,091.

\section{d) Koefisien Korelasi}

Untuk mengetahui hubungan antara variabel bebas terhadap variabel terikat, maka digunakan koefisien korelasi dengan menggunakan bantuan komputer program SPSS for Windows versi 23.0

Jadi dapat dilihat pada tabel dibawah ini:

Tabel 6: Analisis Korelasi

\begin{tabular}{|c|c|c|c|c|}
\hline Model & $\mathbf{R}$ & R Square & $\begin{array}{c}\text { Adjusted R } \\
\text { Square }\end{array}$ & $\begin{array}{c}\text { Std. Error } \\
\text { of the } \\
\text { Estimate }\end{array}$ \\
\hline 1 & $.824^{\mathrm{a}}$ & .678 & .646 & 1.86892 \\
\hline
\end{tabular}

Sumber: Data Olahan SPSS Versi 23.0

Nilai $R$ menunjukkan korelasi berganda antara variabel independen dengan variabel dependen. Dari tabel di atas diketahui nilai $\mathrm{R}$ sebesar 0,824 atau sebesar 82,4\%. Artinya adalah ada hubungan yang sangat kuat dari faktor kebudayaan, sosial, pribadi, psikologis dan bauran pemasaran jasa dengan minat nasabah bergabung di BMT Mutiara Sakinah Pekanbaru, dimana nilai keeratan hubungannya adalah sebesar $82,4 \%$.

\section{e) Koefisien Determinasi}

Diketahui nilai Adjusted $\mathrm{R}$ Square sebesar 0,646. Artinya adalah ada pengaruh yang besar dari faktor kebudayaan, faktor sosial, faktor pribadi, faktor, psikologis dan faktor bauran pemasaran jasa terhadap minat nasabah bergabung di BMT Mutiara Sakinah Pekanbaru, dimana nilainya sebesar $64,6 \%$, sedangkan sisanya sebesar $35,4 \%$ dipengaruhi oleh variabel lain yang tidak diikutsertakan dalam penelitian ini. 


\section{SIMPULAN}

Berdasarkan hasil penelitian di atas diketahui bahwa faktor-faktor yang mempengaruhi minat nasabah bergabung di BMT Mutiara Sakinah Pekanbaru adalah faktor kebudayaan yang terdiri dari beberapa bagian seperti kebudayaan, subbudaya dan kelas sosial; faktor sosial terdiri dari kelompok referensi, keluarga, peran dan status; faktor pribadi terdiri dari umur dan siklus hidup, pekerjaan, keadaan ekonomi, gaya hidup, kepribadian dan konsep diri; faktor psikologis yang terdiri dari motivasi, persepsi, pembelajaran, kepercayaan dan sikap; faktor bauran pemasaran jasa yang terdiri dari produk, harga, tempat, distribusi, promosi dan layanan konsumen.

Dan berdasarkan hasil hipotesis diketahui bahwa; 1) tidak terdapat pengaruh yang signifikan antara kebudayaan terhadap minat nasabah. Hal ini dapat diketahui dari nilai thitung $(1,047)$ lebih kecil dari ttabel (2,009); 2) tidak terdapat pengaruh yang signifikan antara sosial terhadap minat nasabah. Hal ini dapat diketahui dari nilai thitung $(1,016)$ lebih kecil dari tabel (2,009); 3) terdapat pengaruh yang signifikan antara pribadi terhadap minat nasbah. Hal ini dapat diketahui dari nilai thitung $(4,004)$ lebih besar dari ttabel (2,009); 4). Terdapat pengaruh yang signifikan antara psikologis terhadap minat nasabah, hal ini dapat diketahui dari nilai thitung $(5,024)$ lebih besar dari tabel (2,009); 5) tidak terdapat pengaruh yang signifikan antara bauran pemasaran jasa terhadap minat nasabah. Hal ini dapat diketahui dari nilai thitung (485,) lebih kecil dari tabel (2,009).

Maka secara parsial dapat diketahui bahwa faktor yang paling dominan mempengaruhi minat nasabah untuk bergabung di BMT Mutiara Sakinah
Pekanbaru adalah faktor psikologis $\left(\mathrm{X}_{4}\right)$ dengan nilai sebesar 5,024.

Hubungan antara faktor kebudayaan, sosial, pribadi, psikologis dan bauran pemasaran jasa terhadap minat nasabah bergabung di BMT Mutiara Sakinah Pekanbaru termasuk dalam kategori memiliki hubungan yang kuat, hal ini dapat diketahui dari nilai koefisien korelasi (R) sebesar 0,824 yakni sebesar 82,4\%. Dan ada pengaruh yang besar dari faktor kebudayaan, faktor sosial, faktor pribadi, faktor, psikologis dan faktor bauran pemasaran jasa terhadap minat nasabah bergabung di BMT Mutiara Sakinah Pekanbaru, dimana nilai Adjust $R$ Square 0,646 atau sebesar $64,6 \%$, sedangkan sisanya sebesar $35,4 \%$ dipengaruhi oleh variabel lain yang tidak diikutsertakan dalam model ini.

\section{DAFTAR RUJUKAN}

Al-Quran dan Terjemahan

Al-Hadist. (2011). Ayat-ayat dan Hadist Ekonomi Syariah. PT. Raja Grafindo Persada, Jakarta.

Abdullah, Thamrin dan Tantri, Francis. (2012). Bank dan Lembaga Keuangan. PT. Raja Gravindo, Jakarta.

Alma, Buchari. (2011). Manajemen Pemasaran dan Pemasaran Jasa. Alfabeta, Bandung.

Ardianto, Ervinaro. (2010). Metodologi Penelitian untuk Public Relations Kuantitatif dan Kualitatif. Remaja Rosdakarya, Jakarta.

Djaali. (2009). Psikologi Pendidikan. PT. Bumi Aksara, Jakarta.

Hartimbul, F. Nembah. (2011). Manajemen Pemasaran. CV. Yrama Widya, Bandung.

Hasan, Iqbal. (2010). Analisis Data Penelitian dengan Statistik. PT. Bumi Aksara, Jakarta. 
Hermawan, Agus. (2012). Komunikasi Pemasaran. Erlangga, Jakarta.

Huda, Nurul dan Heykal, Mohamad. (2010). Lembaga Keuangan Islam. Kencana, Jakarta.

Idri. (2015). Hadis Ekonomi dalam Perspektif Hadits Nabi. Prenadamedia, Jakarta.

Jahja, Yudrik. (2011). Psikologi Perkembangan. Kencana, Jakarta.

Janwari, Yadi. (2015). Lembaga Keuangan Syariah. Bandung.

Kamus Besar Bahasa Indonesia. (2008). PT. Gramedia Pustaka Utama, Jakarta.

Kasmir. (2014). Bank dan Lembaga Keuangan Lainnya. Jakarta.

Mardani. (2014). Ayat-ayat dan Hadist Ekonomi. Rajawali Pers, Jakarta.

Muhamad. (2008), Metodologi Penelitian Ekonomi Islam. Raja Gravindo, Jakarta.

Nasution, Mustafa Edwin. (2010). Pengenalan Ekskludif Ekonomi Islam. Kencana, Jakarta.

Ridwuan. (2014). Dasar-Dasar Statistika. Alfabeta, Bandung.

Rodoni, Ahmad dan Hamid, Abdul. (2008). Lembaga Keuangan Syariah. Zikrul Hakim, Jakarta.

Santoso, Singgih. (2016). Panduan Lengkap SPSS Versi 23. PT. Elex Media Kompotindo, Jakarta.

Sanusi, Anwar. (2016). Metodologi Penelitian Bisnis. Salemba Empat, Jakarta.

Sardiman. (2014). Interaksi dan Motivasi Belajar Mengajar. PT. Raja Gravindo, Jakarta.

Setiadi, J. Nugroho. (2013). Perilaku Konsumen. Kencana Prenada Media Grup, Jakarta.

Sholihin, Ahmad Ifham. (2010). Buku Pintar Ekonomi Syariah. PT. Gramedia Pustaka Utama, Jakarta.
Slameto. (2010). Belajar dan Faktor-Faktor yang Mempengaruhinya. Rineka Cipta. Jakarta.

Soeharno. (2007). Ekonomi Manajerial. C.V. Andi Offset. Yogyakarta.

Soemitra, Andri. (2010). Bank dan Lembaga Keuangan Syariah. Kencana, Jakarta.

Sunyoto, Danang. (2012). Konsep Dasar Riset Pemasaran dan Perilaku Konsumen. CAPS. Jakarta.

Zulkifli. (2015). Lembaga Keuangan Syariah, Pusat Kajian Pendidikan Islam FAI UIR, Pekanbaru.

Zulfa, M. (2019). Analisis Persepsi Masyarakat Industri Kecil Terhadap Pelaksanaan Pembiayaan Bagi Hasil Bank Riau Kepri Cabang Syariah Pekanbaru. Jurnal Tabarru': Islamic Banking and Finance, 2(1), 1-11. 